
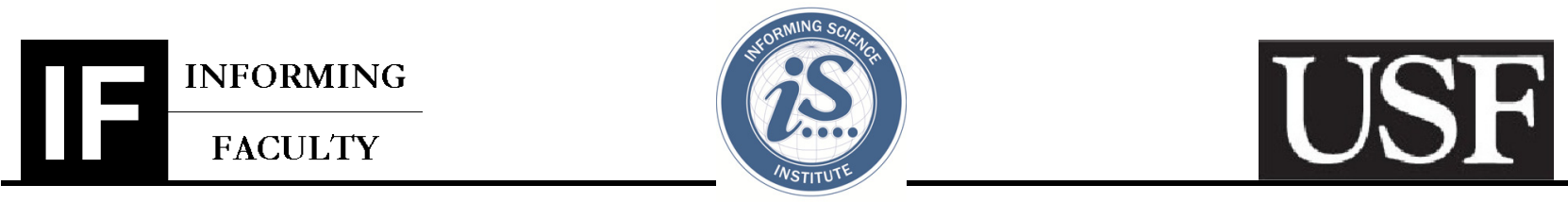

2014-02-4

AUGUST 1, 2014

GRANDON GILL

\title{
LAUNCHING THE DBA PROGRAM AT USF
}

\author{
Everybody agrees that the DBA is a really exciting new program. But are we really going to be \\ able to launch it in a month?
}

Grandon Gill grimaced as he thought about how tight the timetable had become. Just appointed Academic Director of the newly announced Doctor of Business Administration (DBA) program to be offered by the College of Business (COB) at the University of South Florida (USF), it was his job to oversee the process of getting the program up and running. The program - intended to promote doctoral-level study by working executives - was part of a rapidly growing national trend. A variety of factors had conspired to delay the program's final approval, however. As a result, the high level meeting that would make the program "official" was just taking place. Until he got word of that approval, the program could not be advertised and would not have a budget. That would leave roughly one month to market the program before the 1 June 2014 deadline for applications.

That was the "glass half empty" perspective. A more balanced view would recognize that the pace of the program's evolution - in under eight months - had been nothing short of remarkable, especially when contrasted with the typically glacial pace of academic decision-making. The initial decision to design and formally propose the program to the faculty has been made in September 2013. Now, just seven months later, final approval was in the hands of a committee that reported to USF's provost and Chief Academic Officer.

Gill's main short-term concern was ensuring that there were sufficient high quality students to allow the program to run as scheduled. The program's approval was based on its ability to recover all associated costs. Based on its estimated budget, 15 was the targeted minimum enrollment for the first cohort. Gill guessed that perhaps $40 \%$ of this minimum could be met from the dozen or so individuals that had already expressed very strong interest in the program. But how should he go about recruiting the rest? How much money should be devoted to marketing and towards what channels? What if June came and the minimum level had not been achieved? Should the program launch be delayed until January, or should they wait another year?

Then there were the long term questions. How should the program balance selectivity in admissions

\footnotetext{
This case was prepared for the purpose of class discussion, and not to illustrate the effective or ineffective handling of an administrative or classroom situation and is copyrighted by the Informing Science Institute. Permission to make digital or paper copy of part or all of these works for personal or classroom use is granted without fee provided that the copies are not made or distributed for profit or commercial advantage AND that copies 1) bear this notice in full and 2) give the full citation on the first page. It is permissible to abstract these works so long as credit is given. To copy in all other cases or to republish or to post on a server or to redistribute to lists requires specific permission and payment of a fee. Contact Publisher@InformingScience.org to request redistribution permission.
} against providing access to the local constituency? How should it position itself against a rapidly growing number of competitors? In Florida alone, the number of similar executive doctoral programs had grown from zero in 2012 to four in 2014. Finally, there was the 800 pound gorilla: how to ensure that the program design and faculty teaching in the program provided real business value to its executive students. 


\section{Doctoral Programs in Business ${ }^{1}$}

Compared with other academic fields of study, business has a relatively short history. Prior to the early 1900 s, relatively few business schools existed (with University of Pennsylvania's Wharton School of Finance and Dartmouth University's Tuck School being the two earliest), and the MBA degree, introduced by Harvard Business School, was barely a century old. Even these early programs at prestigious institutions were viewed as being far less rigorous than their liberal arts counterparts - such as economics. Their research was, for the most part, considered anecdotal and "lightweight", a stinging criticism in the mind of many academics. There was some justification for these characterizations. In point of fact, most faculty members did not hold terminal degrees and, to the extent they did, these degrees were often in fields that were at best peripherally related to business.

In the late 1950s, the situation came to a head after the publication of two widely circulated reports (supported by the Ford and Carnegie foundations) that offered stinging criticisms of business education and research. Largely in reaction to these criticisms, and with foundation support, in the 1960s academic business research and education began a transformation that continued for several decades. Large numbers of business doctoral candidates were trained in new theoretical and empirical research methods emerging from statistics, economics, and social sciences (such as psychology and sociology). Institutions raised their standards for research and publication. In the process, business scholars gained greater respect across the broader academic community.

As a result of their focus, business Ph.D. programs offered by research institutions in the U.S. were seen strictly as a pathway to an academic career. While some graduates did go into other occupations, such as management consulting, most programs viewed such career decisions with disappointment. In this respect, U.S. attitudes differed from those in certain other countries. Germany, in particular, had a large number of doctorates in its executive ranks - as high as $80 \%$ of large company CEOs by some estimates. Most of these individuals, however, held doctorates in non-management disciplines, such as engineering.

Outside of research universities, the situation was somewhat different. Many online universities, such as the University of Phoenix, University of Maryland, and University College, offered Ph.D. programs in business that could be pursued part-time. The same was true of a number of regionally focused universities, such as Nova Southeastern. While these programs were generally accredited, either by regional or online accrediting agencies, they tended to lack accreditation by the main business accrediting agency, AACSB International. The practical impact of that was to limit the degree to which credits could be transferred across programs. It also meant that AACSB-accredited schools would not normally employ these graduates as faculty members, particularly for tenure earning positions.

\section{U.S. Executive Doctoral Programs in Business}

In recent years, a number of U.S. institutions accredited by $A A C S B$ International began to offer a new type of program that fell outside the academic Ph.D.: the Executive Doctorate in Business (EDB). Although the specific degree awarded varied from institution to institution, with Doctor of Business Administration (DBA) being the most common, they shared a number of features that distinguished them from the traditional business Ph.D. Broadly speaking, these programs served a different set of needs than the Ph.D. (see Exhibit 1). They also tended to share a number of common characteristics (see Exhibit 2).

The first program in this new category was introduced by Case Western Reserve University in 1993, its Executive Doctor of Management (later renamed Doctor of Management). For over 15 years, they represented the only such program in the U.S. In 2009, however, the landscape began to change dramatically as new programs were introduced. This growth and the associated programs are illustrated in Exhibit 3.

${ }^{1}$ Adapted from Gill, T.G. (2013). Executive doctorate in business at USF. USF Case Study. 


\section{Types of curricula}

In analyzing the curriculum content of executive doctoral programs, both in the U.S. and abroad, Gill identified four broad categories of programs: publication, disciplinary, multi-disciplinary, and interdisciplinary. As illustrated in Exhibit 4, these programs all tended to have research methods content near the beginning and a dissertation or project at the end. Where the designs differed was in the middle. As he described them in his blog:

1. By publication. Typical of many European programs, although not in the U.S. Students get some training in research methods and then proceed directly to their dissertation without much-if anycoursework. The Ph.D. is awarded based upon the resulting publication(s).

2. Disciplinary. A direct mapping from the regular Ph.D. to the executive doctorate. Coursework is focused on a specific discipline, often through the use of electives. Students write functional dissertations.

3. Multi-Disciplinary. Survey courses are presented in each functional research area, making the coursework look superficially similar to an MBA (although the content is more focused on the research literature). Students would normally write functionally-oriented dissertations.

4. Inter-disciplinary. Coursework focuses on topics that do not easily fall within a single business function, such as systems theory, analytics, and innovation. Dissertations will often have an interdisciplinary flavor.

Gill continued with his personal assessment of the pros and cons of each design:

1. By publication. Particularly well-suited for individuals who know precisely what questions they want to study prior to entering a program. In Europe, the master's degree often provides this background. The nature of the degree makes it difficult to translate into credits, which might prove an obstacle to teaching at U.S. institutions.

2. Disciplinary. This doctorate is probably best suited to individuals who would like to make contributions to the academic literature, which tends to break down along functional lines. Since business problems rarely break down into purely functional problems, it may prove more difficult to apply to practical problems. Students also should have a good idea of what functional area they plan to concentrate in prior to entering the program.

3. Multi-Disciplinary. Tends to offer a breadth of research literature coverage, well-suited to students who are not sure where their interests lie. Might be particularly useful for executives coming in without a broad-based business degree, such as an MBA. The drawback is that the coverage of so many areas may lead to superficial treatment. Also, it is not clear that the functional research literature is a particularly good source of insights for practice, and executives already practicing in a particular function may find much of it insipid, if not unbelievable.

4. Inter-disciplinary. The content of the curriculum for these programs varies widely, as being interdisciplinary opens up a wide range of possibilities. The inter-disciplinary flavor will, however, provide executives with exposure to areas where they are unlikely to have previous familiarity. Also, the inter-disciplinary focus may make it easier to map what has been learned to "real world" problems.

Of the U.S. programs, Gill characterized the CWRU Doctor of Management as being an excellent exemplar of the inter-disciplinary approach. As shown in Exhibit 5, its course offerings did not fit neatly into typical business functions, instead being focused on systems thinking. The curriculum of Georgia State University's Executive Doctorate in Business was similarly constructed. 
Oklahoma State University's Ph.D. for Business Executives represents an exemplar of the disciplinary focus, faithful to its Ph.D. namesake. Unique among these programs, it offered 3 concentration courses (see Exhibit 6) that allow the student to specialize in a function.

Most recently, a number of multi-disciplinary programs had been launched or announced. Two of these happened to be within a two hour drive of the University of South Florida and were, therefore, of particular interest. A third Florida program, at AACSB-accredited Jacksonville University, was also scheduled to launch in fall 2014. A private university located about 4 hours from USF, and away from other major Florida population centers, it was not deemed to be as much of a competitive threat.

\section{Local Competing Programs}

In fall 2012 the USF COB had first begun exploring the possibility of offering an executive doctorate. At that time, the closest similar program was offered by Georgia State University, in Atlanta. In spring 2013, that situation changed when Rollins College-located in Winter Park, about a 90 minute drive to the west of USF-announced it was launching a program in fall 2013. Rollins was a small liberal arts school that was frequently ranked \#1 among undergraduate regional schools in the South. Its only graduate programs were the various MBA programs offered by its Crummer Graduate School of Business. Both its part-time and Executive MBA programs were ranked highly (at or near the top) among Florida programs. The Executive DBA was to be its first foray into doctoral education. It had launched on schedule in the fall, with a cohort of 13 (three more students than its target of 10). For the fall 2014 cohort, it had raised its 3-year total cost over $\$ 10,000$ from its original $\$ 68,000$ offering price.

In fall 2013, the University of Florida (UF) - the state's well known flagship university located in Gainesville, about 2 hours north of USF - announced that it would be offering a market rate DBA program. A market rate offering differed from the "cost recovery" model being launched by USF in two ways:

1. It was allowed to have revenues in excess of costs

2. It required approval from the Florida Board of Governors, the body responsible for oversight of the state university system. That approval was received in November 2013.

Similar to cost recovery programs, the authorization of the UF DBA was dependent upon the fact that UF was already offering Ph.D. degrees in business. That meant that the DBA did not represent a new degree, only a new variation on the existing degree. This distinction was crucial, since new Ph.D. degrees required a lengthy approval process, often taking 5 years or more. The first public presence of the UF DBA appeared in early 2014, when the program website was unveiled.

The curriculum and costs of the two Florida programs are summarized in Exhibit 7. Based upon the curricula posted on their websites, both appeared to be leaning heavily towards the multi-disciplinary model. Both had a full set of functional offerings and courses of a type frequently found in MBA programs (bolded in the Rollins slide in Exhibit 7; highlighted in the UF slide in Exhibit 7). From a faculty assignment standpoint, such a curriculum was the easiest to support, since it mimicked the course subject areas taught in MBA and Ph.D. programs, as well as the research areas of most faculty members. In doing so, however, both programs departed significantly from the highly successful CWRU and GSU programs, both of which were interdisciplinary.

On a cost basis, the programs were reasonably close. The $\$ 90,0003$-year price at UF included meals, books and a computer. The Rollins 3-year price of $\$ 78,500$ included none of these, making its effective cost (for comparison purposes) somewhere closer to $\$ 85,000$. 


\section{The USF College of Business ${ }^{2}$}

Over its short lifetime, the University of South Florida, located in Tampa, had experienced a rise in stature matched by few other institutions in the world. Founded in 1956, by 2013 the university had transformed itself into a system soon to consist of three separately accredited institutions (the Tampa/Main campus, USF St. Petersburg, and USF Sarasota/Manatee) that covered most of the west-central region of the state. It was the eighth largest public university in the U.S. and was among 108 institutions classified by Carnegie as research university/very high $(\mathrm{RU} / \mathrm{VH})$.

With around 6,000 students, USF's College of Business (COB) was second in size only to USF's College of Arts \& Sciences. In addition to its SACS regional accreditation (shared with the university as a whole), its business and accounting programs were accredited by AACSB International. The college reported approximately 105 faculty/staff (full time equivalent) and a $\$ 15$ million operating budget.

The largest programs in the COB were its undergraduate programs in business and accounting, with total enrollment of approximately 5,000. At the graduate level the college boasted a wide range of programs, including doctoral degrees, disciplinary master's degree programs, an MBA program and an Executive MBA program. Recently, the COB's Information Systems \& Decision Sciences department Master of Science in MIS (MS-MIS) program garnered considerable university attention as a result of having well in excess of 800 applicants for slots in fall 2014, nearly all of whom were international students.

A particular area of challenge for the College related to its $\mathrm{PhD}$. programs, described as follows on the College's website:

Doctoral programs at the USF College of Business are specifically designed for scholars who aspire to become research faculty at top-tier institutions worldwide. Transforming young scholars into world-class researchers, this rigorous $\mathrm{PhD}$ program provides students with broad training in the latest research methodology as well as experience in the business classroom.

The USF College of Business is committed to providing scholars with the coursework and handson inquiry to enable their research and discovery to be published in high-quality academic journals. The College provides a level of training that will bring students to the forefront of their chosen area of study. Candidates are mentored as they complete independent inquiry and enjoy numerous opportunities to work side-by-side with respected research faculty in collaborative research programs.

Placement assistance is provided as graduates begin their academic careers at leading research institutions.

$\mathrm{PhD}$ concentrations are offered in the areas of accounting, finance, marketing, and information systems.

In many respects, these programs were exemplary - offering rigorous training to students and experiencing student attrition rates that were far lower than some of its peer competitors. The faculty members teaching in the programs were also internationally renowned - at least two of USF's departments had faculty research or program rankings in the top 50 (out of more than 4,000 higher education institutions in the U.S.) Unfortunately, its placement record at "top-tier institutions" was far below what the quality of its programs would imply.

\footnotetext{
${ }^{2}$ The next two sections are adapted from Gill, T.G. (2013). Executive doctorate in business at USF. USF Case Study.
} 


\section{USF DBA Program}

The initial impetus for launching an executive doctorate at USF resulted from a conversation between Dr. Moez Limayem and Gill. Limayem, the former Associate Dean at the Sam Walton College of Business at the University of Arkansas, had just joined the USF College of Business as dean in July 2012. Upon arriving at the college, he announced that he would be making no major changes until he had spoken one-onone with each of the full-time faculty members. True to his word, he had scheduled nearly 100 meetings (up to an hour each) over a two month period. At each meeting, his central question had been the following: What are your ideas for making the USF College of Business better?

At one of these meetings, he was surprised to hear Grandon Gill, professor in the Information Systems \& Decision Sciences (IS\&DS) department, proposing an idea that Limayem himself had been aggressively pursuing prior to leaving his previous position: launching an executive doctorate. Perhaps even more surprising, Gill had published research on the subject in the International Journal of Doctoral Studies and had been quoted as an expert on the subject in a Bloomberg BusinessWeek article published in 2010.

Limayem realized that he would need to engage all his stakeholders if he was going to successfully move the project forward. Nothing in a university ever succeeds against the will of faculty. The administration's reaction was also important, since the university was in a state of fiscal retrenchment rather than growth; he would need to present a compelling argument for its economics. Interestingly, for this particular project two of the key stakeholders - the students and the leaders of the business community - might well be one and the same. Finally, there was the State of Florida to consider. It had indicated it would not approve duplicate programs within the state system. While no such program was presently being offered elsewhere within the state university system, Limayem doubted that this situation would remain true for long.

\section{Evolution of the DBA Program}

As the end of his "listening phase" approached, Limayem decided to form an informal "Special Projects" committee to look into the executive doctorate in business as well as a number of other innovative ideas that had been proposed to him. The committee, consisted of himself, the Associate Dean, the Marketing department chair and a senior faculty member (Gill, the original proposer). After refining the original concept in a number of ways, and conducting a survey to determine the potential interest of alumni of the COB's EMBA program - the group concluded that the overall idea behind the program was sound. By September 2013, the decision had been made to form a committee to develop a program design that could be put forward for approval by various faculty committees and the COB faculty as a whole.

Shortly after the committee had been formed in fall 2013, it received a piece of good news. Based upon an administrative interpretation of the statutes, so long as a proposed executive doctoral program was reasonably consistent with USF's existing Ph.D. program, it would not be considered a new doctorate. Instead, it would be treated more like a new doctoral concentration-something that could be approved internally in a much shorter period of time. It was further determined that the program could be funded as a cost recovery program. This model seemed to be a good fit for two reasons:

1. In order to make a profit, a very high tuition rate would need to be set. Given the substantially lower tuition being charged by Rollins at the time ( $\$ 68,000$ over 3 years), this seemed risky.

2. Cost recovery programs could be approved locally; market rate programs required approval from the Florida Board of Governors. This process was independent of any other program approvals that might be required, and would likely add a year to the launch date.

Having made this decision, it became feasible to consider offering the program as early as fall 2014. Meeting regularly during the fall semester, the committee-chaired by Gill-designed the curriculum and prepared a graduate catalog page for approval by the college doctoral committee and the full college faculty. These approvals were given by unanimous vote in December 2013. 
The next step was getting the university's Graduate Council to approve the program. Several speed bumps regarding the course content were encountered during this process. Many of the courses in the original proposal had been listed as "special topics". This was actually a matter of intent; in designing the program the committee had opted for as much flexibility as possible. This would allow faculty members (and even DBA students) to propose new courses frequently. To address the council's concerns, the committee ended up creating formal proposals for those new courses that were already planned for the first cohort. It also created proposals for a series of "Issues" courses-whose topics were not pre-specified-that filled slots at the end of the program. These actions-which required another hastily called faculty meetingsatisfied the university council and they approved the program.

Further delaying the approval was one final hiccup. A number of potential applicants had complained stridently about the use of the term "Executive" in the degree. They indicated that a straight "Doctor of Business Administration" was preferable. Since it would be much easier to make such a change before the program was launched, the name change was proposed and went through another round of approvals. This time, two meetings of the full faculty were required, since the first lacked a quorum. But the end result was the same: unanimous approval. The name change request was passed on to the USF Graduate Council and, by mid-March, the proposed program became a Doctor of Business Administration. The final approval step involved a committee that reported to the USF's Provost, responsible for the academic affairs of the university, which would not meet until late-April.

\section{DBA Program Design}

The key elements of the USF DBA program are summarized in Exhibit 8. The specific design was influenced by a number of factors:

- Its requirements needed to conform as closely as possible to the COB's existing Ph.D. program, since it was better viewed as a variation of that program, not a new program. That meant that required core courses - primarily research and quantitative methods - for both Ph.D. and DBA were the same.

- It needed to conform to university doctoral requirements for committees and credits, including a newly specified 72 credit requirement for doctoral programs. By designing the program to this number of credits, it became possible to consider unusually qualified students who might enter without the Master's degree that was a prerequisite for most programs.

- It needed to be priced attractively in comparison with its competition, particularly the UF DBA program.

With respect to pricing, the USF program offered a twist. Based upon Gill's discussions with DBA graduates and candidates at an annual meeting of the Executive DBA Council, an organization created to help publicize and advance executive doctoral programs globally, it was clear that students generally encountered substantial out-of-pocket expenses for travel and research supplies while enrolled in their respective programs. This mirrored Gill's own experiences at Harvard Business School in the mid-1980s, where he had been given a $\$ 10,000$ budget to cover such expenses during his DBA candidacy. For this reason, the committee had decided to provide each student with an account for up to $\$ 6000$ to cover such expenses.

The committee had also decided to require each student to attend at least three faculty conferences, workshops, or symposia while enrolled in the program (providing another justification for the student expense budget). This requirement was driven by the program's stated goal of graduating future research partners. Whereas a traditional Ph.D. program might seek to replicate the skills and values of successful faculty in its graduates, such was never the goal of the DBA program. Instead its twin objectives were to graduate executives who could (1) apply rigorous research methods to their own business challenges and (2) build effective partnership relationships with researchers in order to solve problems and uncover new truths about the world. In order to achieve the second of these objectives, it was critical that graduates were comfortable interacting with researchers in their own preferred venues. 


\section{USF DBA Program Curriculum}

The USF DBA program's curriculum, illustrated graphically in Exhibit 9, was heavily inspired by the interdisciplinary philosophy of the CSRU and GSU programs. It added its own unique twist by classifying courses into 6 categories. Gill described these in his $\operatorname{blog}^{3}$ as follows:

1. Research Courses: These courses provide coverage of research methods. As a doctorate, research is central to the DBA. Where it differs from a Ph.D. is that these courses will be more focused on how research techniques can be applied for the purposes of enhancing practice, as opposed to being conducted for the purpose of generating insights suitable for publication.

2. Strategic Focus Courses: The USF College of Business has adopted a number of areas of focus for its research and teaching activities, including analytics, creativity/innovation, and sustainability. These focus areas involve the type of interdisciplinary thinking that our DBA program was developed to encourage. By including them in the program, we are encouraging both students and faculty to incorporate them in their research agendas.

3. Publication Courses: Although the DBA is not a program that emphasizes publication as its principal source of value, we nevertheless recognize and revere the discipline and rigor that writing for peer review and publication instills. These courses are intended produce publishable student works, and will include peer review components in which students provide constructive feedback on each other's efforts. They will normally be paired with another course, which will provide the background needed to conduct publishable research in a particular area. By the middle of the second year, students will have completed three such courses. Hopefully, this will make the thought of completing a larger dissertation project less intimidating.

4. Special Topics Courses: These courses are proposed by faculty members and are likely to change with every cohort. The goal is to provide students with an in-depth introduction into a particular researcher's area of passionate interest.

5. Issues Courses: These are short (2-credit) courses that could be characterized as weekend workshops. Because they run in parallel with dissertation courses, they are intended to place a modest workload on the students between sessions. They are a unique aspect of the program because 2 nd year students will have considerable say in what courses are offered-including the ability to propose topics-and may even be allowed to co-teach a course with an experienced faculty member.

6. Dissertation and Dissertation Preparation Courses: These 4-credit courses, starting at the end of the student's second year and running throughout the student's final year, provide students with the opportunity to complete and document a large research project under the direction of a 4 person faculty committee chaired by the student's major professor. Considerable flexibility is afforded the student in choosing a topic and how the dissertation is presented (e.g., traditional dissertation, book, series of articles, project white paper), subject to approval by the student's committee.

The issues courses (see 5 above), in particular, were included to present students the opportunity to become involved in designing their own learning. While such involvement was unique in U.S. programs, it was completely consistent with USF's objective of building graduates who were suitable partners for, rather than replicas of, the research faculty who had acted as their instructors/facilitators in the program. Gill had considered the difference between creating partners and replicas in a posting to his blog (Exhibit 10).

\footnotetext{
${ }^{3}$ http://grandon.com/blog/?p=368
} 


\section{The Program Launch}

By late April 2014, final approval of the program was imminent and the pressure to ensure a successful launch was building. A variety of activities were taking place in parallel.

\section{DBA Program Committee}

The DBA Program Committee was charged with general oversight of the program as well as a variety of specific important activities, such as approving the program's course content and formation of dissertation committee teams in each cohort's second year. This committee had a representative from each department, as well as Gill and an Associate Dean.

By the second week of April, the members of the committee had finally been named. The long delay had been the result of the program's nature. As a cost recovery program, all faculty DBA committee assignments had to be both voluntary and compensated (in order to be included in the program's full cost). Since it was doubtful that pre-launch efforts would be compensated retroactively, identifying suitable individuals who were ready to be active participants prior to launch proved to be challenging-especially from those departments that did not anticipate becoming actively involved in the program's first year.

And busy the committee was expected to be. The ambitious proposed agenda for its first meeting included:

- Revising and then approving a draft of the committee policies and procedures document

- Approving course proposals for the first year

- Approving the 2014-2015 calendar

- Approving the program's application form

- Discussing the program's website and its expected evolution

- Discussing the timing and organization of marketing sessions and a research workshop to be held before the program's scheduled orientation session in mid-July

- Discussing the marketing efforts for the founding cohort

When the actual meeting took place, the group had discussed each of the issues and planned to begin making decisions the week that followed, after program approval.

\section{Websites}

Since early March 2014, Gill and Jason Zipperer, webmaster for the USF COB, had been putting together a "development" version of the program's website (see Exhibit 11). The deployment of the website was heavily constrained by a number of factors. First, the university's mandated content management system (CMS) specified the appearance and basic structural elements of the website. Second, key details of interest to students - such as information session and class meeting dates - had been unavailable. Third, lacking a budget, certain types of content — such as high quality videos of faculty members discussing the courses that they would be offering - could not be produced. Finally, prior to official university approval, care had to be taken to avoid making any statement that a potential applicant might take to be a promise.

Faced with these constraints, Gill had started placing "unofficial" content and videos on his personal website (see Exhibit 12). Not funded by USF and continually asserting its unofficial nature, it offered considerable flexibility. Launched in late March, the page hosted a variety of documents and case studies, web links to other programs, articles and useful sites (such as the Executive DBA Council), a series of postings on Gill's blog and well over an hour of video (hosted on YouTube), discussing DBA programs in general and Gill's personal take on the USF program. After a potential applicant contacted Gill, he offered the website as a potential source of information while the program awaited final approval. 


\section{Recruiting Status}

Recruiting students for a program that was yet to be approved without any marketing budget presented a bit of a challenge. Three different approaches were being employed:

1. EMBA Alumni Survey

2. Other email mailing lists

3. Word-of-mouth

These channels produced differing levels of response.

\section{EMBA alumni survey}

In spring 2013, while the feasibility of the program was still being considered, the COB had sent out an email survey to approximately 300 EMBA alumni for whom email addresses were on file. The results were as follows:

- 97 responses were returned

- $46(47 \%)$ indicated an interest in attending the program,

- Another $22(22 \%)$ indicated that they might be interested.

- 42 of the 46 most interested group indicated that they were willing to be contacted again and supplied their email addresses.

A year later, in late March 2014, a follow-up survey was sent to the group of the 42 most interested respondents. The follow-up survey differed from the original survey in two important ways: 1) it was much shorter, consisting of two question aside from contact information, 2) it included the actual price of the program, which was substantially higher than the median price range $(\$ 15,000-\$ 25,000 /$ year $)$ judged by respondents to be "appropriate" in the prior survey. Half of the surveys (21) were returned, with the following distribution:

- $5(24 \%)$ indicated that they were interested in applying for the cohort starting in fall 2014.

- $4(19 \%)$ indicated that they were interested in applying for some future cohort

- $6(29 \%)$ indicated that they might be interested in applying for some future cohort

- $6(29 \%)$ indicated that they were not interested

Gill periodically sent out emails to the group of 5 thinking about applying for the founding cohort, encouraging them to stay in touch.

\section{Other email mailing lists}

To spread awareness of the program, as well as to get a sense of response rates, emails announcing the imminent launch of the program and providing a link to the development website had been sent, or were about to be sent, to two groups:

- Members of the departmental Executive Advisory Boards for the IS\&DS, Marketing and Accounting departments. Collectively, these consisted of 65 executive-level volunteers from the local business community. The email particularly encouraged them to forward the information to any other individuals that they thought might be interested.

- USF Alumni "Fast 56" awardees. Each year, the 56 fastest growing company's led by USF alumni were honored at a dinner, held on 11 April in 2014. (The number 56 in honor of USF's 1956 founding date). The director of the USF Alumni Association had indicated that this was a good potential test market and had agreed to announce the program and include a link to the DBA development website as part of a congratulatory email to be sent out following the dinner.

Thus far, no returns from the first set of emails had been received. The second set would go out the week after approval was finalized. 


\section{Word-of-mouth}

Thus far, word-of-mouth had proven to be the most effective recruiting tool. Through referrals from the COB Dean and the MBA office, seven strong prospects had been identified. Gill had already met with four of these for informational interviews, all of whom seemed to be strong candidates with high levels of motivation. He had also had extensive email correspondence with the remainder, including more than a dozen back and forth exchanges with one.

\section{Gill's assessment}

Given that enthusiasm was different from commitment, Gill guessed that of the 5 EMBA and 7 word-ofmouth prospects, perhaps half would actually both commit and prove to be a suitable fit for the program. If he was correct, then perhaps $40 \%$ of the initial minimum desirable cohort size of 15 had been identified. That meant to meet the programs goals, another 9 solid applicants who would follow through and join the program had to be acquired by the June $1^{\text {st }}$ application deadline.

\section{The Questions}

The coming weeks would prove crucial for the launch of the program. Gill had identified at least four questions requiring decisions that had both short term and long term implications for the program. And they all needed to be addressed in the very near future.

\section{How Should the Program Be Marketed?}

While awaiting forthcoming official approval of the program, the program had made no investment in marketing. Instead, as described earlier, it had relied upon local email lists and word-of-mouth. Now that full approval was imminent, that was likely to change. But how it would change, and how much to invest, were far from clear.

Gill had received one estimate, in excess of $\$ 50,000$, that proposed splitting marketing dollars roughly evenly between print media and web/broadcast media. He had some serious concerns with this strategy, since much of the print advertising would not appear until early June or right before. Given that USF's graduate application deadline for "full consideration" was 1 June 2014, he was concerned that the print portion, in particular, would not yield many current year applications. On the other hand, he had been informed that it would still be possible to consider applications made after the deadline - although this would become very challenging logistically (e.g., for book and computer orders) as the end of June approached. Also, many people who did not apply this year might consider applying in the future once they became aware of the program, so the expenditure would not necessarily be wasted.

Another possibility would be to minimize expenditures and focus more aggressively on alumni channels. This group was already invested in relationships with USF and would likely be more forgiving if the launch had to be delayed owing to insufficient initial enrollment.

The marketing decision also had significant competitive implications. A few months before, an advertisement for the Rollins EDBA program had started appearing on a massive electronic billboard located on the interstate highway that ran from St. Petersburg to Tampa, past the Tampa International Airport. As shown in Exhibit 13, this location could be considered just at the edge of reasonable back and forth commuting distance to the weekend residencies of the Rollins program. Given the size of the Greater Tampa Bay Metropolitan Area-roughly double that of Orlando - it made sense that the Rollins program hoped to draw from USF's service area. Would it be wise for the USF to respond with its current low profile strategy? Or would it be better to increase the USF DBA program's visibility dramatically?

There was yet one further concern. Suppose a concerted marketing effort succeeded too well? While having too many applicants sounded like a nice problem to have, the target market for the program was leaders of the local business community. Many of these individuals were strong supporters of the school and 
its students. What would happen to that relationship with USF if they were rejected from a program that has been specifically designed to meet the needs of individuals like themselves?

\section{What Should the Go-No Go Point for the Scheduled Launch Be?}

Thus far, there was no evidence that any of the executive doctorates at AACSB-accredited institutions had run into problems meeting enrollment targets. On the other hand, to the best of Gill's knowledge there had been no programs that had been so compressed in their recruiting timetable. The newly launched program at Temple University, for example, had started active marketing for its fall 2014 founding cohort by September 2013. Even UF had a three month head start on USF. The question then became at what level of enrollment does it make sense to postpone the launch.

This was not an easy question to answer. The nominal break even for the program appeared to be about 15 students. Even that, however, could not be considered a "hard" number. As shown in Exhibit 14, the program had a variety of costs that could be broken down in two important dimensions:

- Variable versus fixed. Most of the individual program cost items (shown in italics) depended on the number of student or student credit hours $(\mathrm{SCH})$, making them variable. The two important exceptions to this were administrative costs and faculty costs - the two largest cost items, making up more than $50 \%$ of the total. Faculty costs were not entirely fixed, however. While course instruction during the first two years would not vary, the cost of dissertation committees would be proportional to the number of students. Thus, in total, Gill estimated that at 15 students, about $60 \%$ of costs were variable, $40 \%$ fixed.

- Direct versus indirect: Three costs - direct student costs, faculty costs and administration - were incurred as a direct result of student activities. These accounted for roughly $70 \%$ of all program expenses. The remaining costs were either required by the university (e.g., student fees, which included a per-SCH charge for athletic facilities and student organizations) or built into the cost recovery model (e.g., professional development). If the program was not offered, these overhead costs would not go away. They would simply need to be allocated to other programs. It might be possible to defer some of the courses while the program was ramping up, although they would need to be paid eventually, either by the program or the COB (in the event the program was to be discontinued).

Taking this cost structure into consideration, it might be possible to launch with a number of students smaller than 15, particularly if large, up-front marketing costs were not incurred.

The question of minimum cohort size was not purely economic, however. A very small initial cohort might be viewed as symptomatic of a weak program, which could impact its long term viability. Postponement of the launch, on the other hand, might sap the considerable momentum that the program had generated within the COB. Certainly, it would be a disappointment to those potential applicants who had already arranged their schedule for a summer start.

Even if the program launch were to be postponed, the question of "to when" needed to be answered. All of the programs listed in Exhibit 3 appeared to conform to the academic calendar, beginning at some point around the start of the fall semester. Outside of academic habits, however, there seemed little reason for a program to begin at that time. In fact, a program that started in January might well be attractive to some potential applications. Or, it might eliminate the program from contention among individuals who were comparing programs as part of making their application decision.

And then came another complication... Earlier in the week, another potential source of candidates had surfaced. A student from the first year EMBA cohort had asked Gill about the possibility of transferring to the DBA program without completing the second year of the EMBA. In a later email, he had indicated that a couple of his classmates were also interested in the same opportunity - one of whom had already contacted Gill. The question of how to proceed was a delicate one: Was raiding the successful EMBA 
program really a viable, or even ethical, source of students? Or, perhaps, it could be considered an opportunity: the creation of a track - the first year of the EMBA followed by the three year DBA program - for students who wanted a doctorate but came in without any graduate credits.

\section{Who is the Program's Long Term Constituency?}

Short term decisions such as marketing budgets and go/no-go cut points could not (or, at least, should not) be made without considering their long term strategic implications. The most important of these decisions involved identifying the long term constituency of the programs.

The most successful early program launches — specifically those of CWRU, GSU and OSU—all drew students from a national pool of candidates. CWRU had the benefit of being the only game in town. For GSU, this was aided by being located an easy train ride from the nation's largest airport hub. For OSU, situated in a metropolitan area of less than a million people, it was probably a necessity.

There were a number of advantages to drawing on a national (or at least large regional) base. Among these:

- It facilitated achieving national recognition for their programs. Universities prized such flagship programs, and were often willing to commit substantial resources to ensure their success.

- It reduced the risk that the program might exhaust its local market of interested executives.

- It increased the amount of tuition that could be charged.

It was unclear to Gill how long the window of opportunity for rapidly establishing a national presence would last, however. As shown previously in Exhibit 13, the state of Florida was already home to four programs, and he had little doubt that one or more programs would emerge in the Miami area —although none had been announced.

Gill wondered if it was realistic for USF to target a national presence. Given that the state's flagship university (UF) had no choice but to go outside its commuter region (given the small size of the Gainesville metropolitan area, as noted in Exhibit 13), could the area really support two programs competing for students state-wide or nationally?

He also wondered if it was even desirable. Given his philosophy of educating future partners, having the bulk of students coming from the local area seemed to make sense. But it was unlikely that everyone in the COB and administration shared his personal views. To launch a DBA program that quicklyestablishing national prominence along the way-would be a huge feather in both the COB's and the university's cap. The prestige associated with such an offering was, perhaps, too great a potential prize to forgo.

The DBA program's strategic focus would impact virtually every aspect of its design and execution. A nationally focused program would have an entirely different marketing plan, most likely tougher admissions standards, higher tuition, and, perhaps, would entail bringing in more high profile outside faculty members to raise its profile. A local focus would involve more word-of-mouth, more affordable tuition, admissions standards that placed more weight on the potential for ongoing relationships after the program ended, and almost complete reliance on USF research faculty along with graduates of the program who could serve on dissertation committees and teach some specialized issues courses.

While the decision on how to focus the program would probably not be locked in stone based upon the make-up of the founding cohort, Gill felt that the decisions made over the coming month would certainly make it easier or harder to follow a particular path. 


\section{What Can Be Done to Make the Program More Attractive to Students and Faculty?}

Ironically, the pressing questions that were currently occupying Gill's mind were generally considered to be the minor ones. When he had attended the EDBAC meeting back in September 2013, everyone involved with a successful program warned him that the two major issues were:

1. Ensuring that the college's faculty were broadly engaged in the program. The term "nightmare" was one of the least intimidating terms used to describe the process of recruiting faculty advisors and matching them with students.

2. Ensuring that the program offered a strong value proposition to students. Faculty and executive practitioners existed in very different worlds and it was very easy for both to become confused regarding the purpose of a program that was intended to bring the two worlds together. For faculty, this meant understanding that a DBA was not a Ph.D. For students, that it was not an advanced MBA, but a degree intended to help them learn how to conduct research that was both rigorous and useful.

Gill was cautiously optimistic that USF could address these issues successfully. At that EDBAC meeting, he had also heard many horror stories about getting these programs approved. In fact, he had not heard of any program making though the approval process smoothly. As a result of the strong support of the dean and the tireless efforts of the numerous committees involved, however, the process at USF had been extraordinarily harmonious (by academic standards, anyway). Perhaps they could continue to make choices that would minimize the expected growing pains - or at least make them less debilitating.

A promising start was no guarantee of future performance. Ultimately, the long term success of the program would depend heavily upon finding good answers to these and other questions. 


\section{Exhibit 1: Comparing DBA and Ph.D.}

\begin{tabular}{|c|c|c|}
\hline Issue & DBA/Executive Doctorate & Ph.D. \\
\hline $\begin{array}{l}\text { Want a career as a full-time tenured } \\
\text { academic and researcher }\end{array}$ & Unlikely to fit & $\begin{array}{c}\text { Possible fit }- \text { good fit when from a top } \\
\text { research school }\end{array}$ \\
\hline Want to work while getting the degree & Good fit & Unlikely to fit \\
\hline $\begin{array}{l}\text { Want to develop research skills slanted } \\
\text { towards practice }\end{array}$ & Good fit & Weak fit \\
\hline $\begin{array}{l}\text { Want to develop research skills slanted } \\
\text { towards publication }\end{array}$ & $\begin{array}{c}\text { Possible fit-depends on the type of } \\
\text { publication }\end{array}$ & Good fit \\
\hline $\begin{array}{l}\text { Want to learn more about operating a } \\
\text { business }\end{array}$ & Weak fit & Terrible fit \\
\hline $\begin{array}{l}\text { Want a high probability of successful } \\
\text { completion in predictable time }\end{array}$ & Good fit & Weak fit \\
\hline Uncomfortable with math and statistics & Possible fit-depends on program & Weak fit \\
\hline Worried about the money & Weak fit & $\begin{array}{l}\text { Good short term fit, Terrible long term } \\
\text { fit (from ROI perspective) }\end{array}$ \\
\hline
\end{tabular}

Source: Case writer slide show 


\section{Exhibit 2: Common Program Characteristics}

- Designed for working professionals

- Require substantial work experience (10-15 years)

- Students take classes as a cohort (10-30 students)

- Series of short residencies (2-3 days, on weekends)

- Expect 10-20 hours outside work per week

- Dissertation requirement more flexible than Ph.D.

- Substantial financial commitment $(\$ 75,000-\$ 150,000$ program total)

- Not intended to prepare students for tenure track positions

Source: Case writer slide show 


\section{Exhibit 3: U.S. Executive Doctorates at AACSB-accredited Institutions}

\section{U.S. Programs at AACSB accredited institutions}

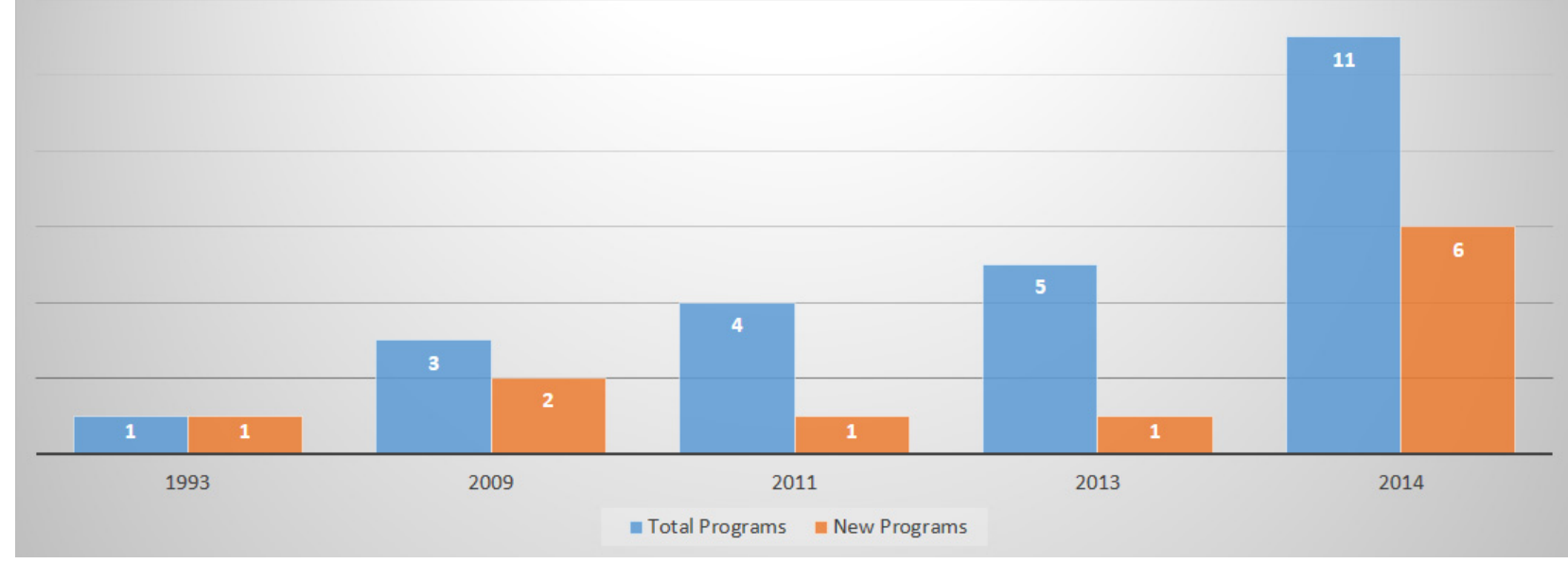

Source: Case writer slide show

U.S. Executive Doctorates at AACSB-accredited schools
\begin{tabular}{|l|l|l|}
\hline Year & \multicolumn{1}{|c|}{ Program } & \multicolumn{1}{c|}{ Total Cost } \\
\hline 1993 & Case Western Reserve University & $\$ 150,000$ \\
\hline 2009 & Georgia State University & $\$ 109,000$ \\
\hline 2009 & Kennesaw State University & $\$ 96,500$ \\
\hline 2012 & Oklahoma State University & $\$ 120,000$ \\
\hline 2013 & Rollins College & $\$ 78,192$ \\
\hline 2014 & Jacksonville University & $\$ 81,000$ \\
\hline 2014 & Temple University & $\$ 126,000$ \\
\hline 2014 & University of Dallas & $\$ 84,000$ \\
\hline 2014 & University of Florida & $\$ 90,000$ \\
\hline 2014 & University of South Florida & $\$ 90,000$ [Note 1] \\
\hline $\begin{array}{l}\text { Note 1:USF program tuition includes } \$ 6,000 / \text { student budget for reimbursement of student } \\
\text { research-related expenses }\end{array}$ \\
\hline
\end{tabular}

Source: http://grandon.com/index.php?pageid=dba.php 


\section{Exhibit 4: Four Flavors of Executive Doctorate}

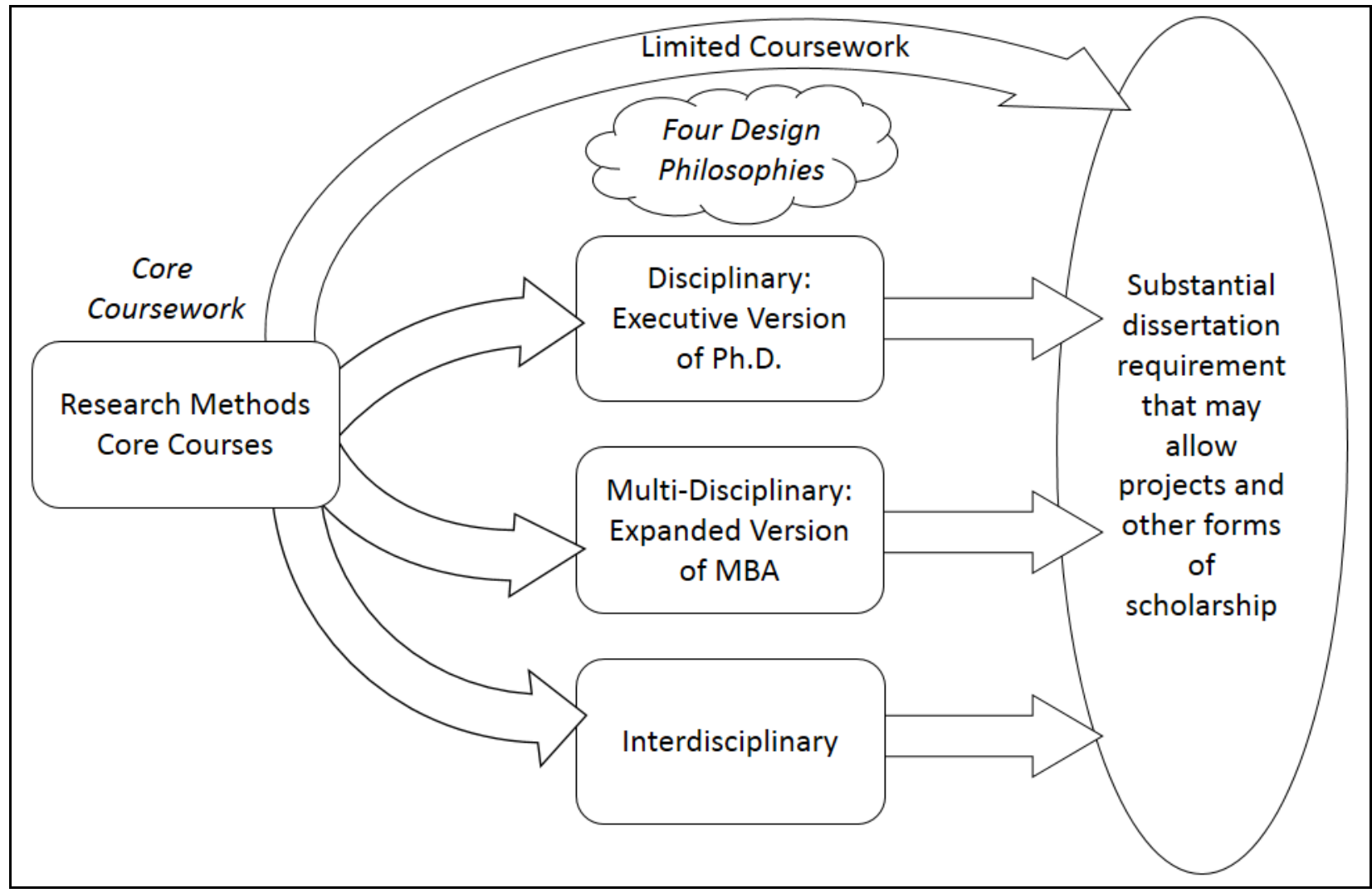

Source: Case writer blog (http://grandon.com/blog/?p=360) 
Case Western Reserve University's Doctor of Management curriculum:

\begin{tabular}{|c|c|c|c|}
\hline Year & Fall & Spring & Summer \\
\hline 1 & $\begin{array}{l}\text { - Conflict and Cooperation in } \\
\text { the Global Arena } \\
\text { - Leading Change } \\
\text { - Introduction to Research } \\
\text { Methods }\end{array}$ & $\begin{array}{l}\text { - Systems Thinking and Complex Systems } \\
\text { - Structured Qualitative Research Methods I } \\
\text { - Theories of Decision of Making } \\
\text { - Deliverables: ॰A Conceptual Paper (CP) } \\
\text { which includes the student's research pro- } \\
\text { posal is due in the second semester of } \\
\text { Year One. }\end{array}$ & $\begin{array}{l}\text { 2-day workshop } \\
\text { on Qualitative } \\
\text { Research Meth- } \\
\text { ods }\end{array}$ \\
\hline 2 & 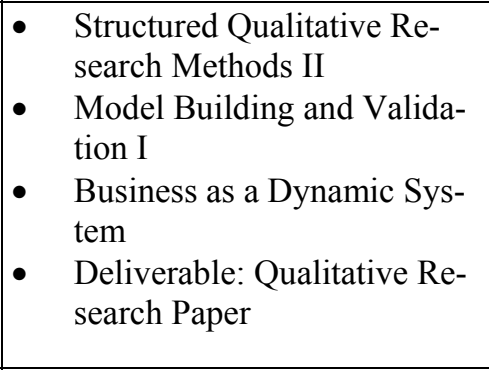 & $\begin{array}{l}\text { - } \quad \text { Leadership, Sustainability and the Global } \\
\text { Agenda } \\
\text { - } \quad \text { Model Building and Validation II } \\
\text { - } \quad \text { Foundations of Quantitative Research }\end{array}$ & $\begin{array}{l}\text { 2-day workshop } \\
\text { on Quantitative } \\
\text { Research Meth- } \\
\text { ods } \\
\text { Deliverables: } \\
\text { Capstone exam } \\
\text { on Quantitative } \\
\text { Research Meth- } \\
\text { ods } \\
\end{array}$ \\
\hline 3 & $\begin{array}{ll}\text { - } & \text { Technology and Social Sys- } \\
& \text { tem Design } \\
\text { - } & \text { Critical Mixed Method Re- } \\
\text { search Issues } \\
\text { - } \\
\text { Advanced Analytical Meth- } \\
\text { ods } \\
\text { - Deliverable: Quantitative } \\
\text { Research Paper }\end{array}$ & $\begin{array}{ll}\text { - } & \text { Research Dissemination } \\
\text { - } & \text { Designing Sustainable Systems Project } \\
\text { - } & \text { Theories of Organizing }\end{array}$ & \\
\hline
\end{tabular}

\section{Source: Gill, T.G. (2013). Executive doctorate in business at USF. USF Case Study.}


Oklahoma State University's Executive Ph.D. curriculum:

\begin{tabular}{|c|c|c|c|}
\hline & Spring & Summer & Fall \\
\hline \multirow[t]{3}{*}{$\begin{array}{l}\text { Year } \\
1\end{array}$} & $\begin{array}{l}\text { BADM } 6513 \\
\text { Organizational Sciences I }\end{array}$ & $\begin{array}{l}\text { BADM } 6713 \\
\text { Theory Building and Scientific Re- } \\
\text { search } \\
\text { (Qualitative Methods) }\end{array}$ & $\begin{array}{l}\text { MSIS } 6343 \\
\text { Quantitative Methods }\end{array}$ \\
\hline & $\begin{array}{l}\text { BADM } 6523 \\
\text { Organizational Sciences II }\end{array}$ & $\begin{array}{l}\text { MGTM } 6353 \\
\text { Advanced Methods in Management } \\
\text { Research } \\
\text { (Research Methods II) }\end{array}$ & $\begin{array}{l}\text { BADM } 6100 \\
\text { Applied Research Practi- } \\
\text { cum I }\end{array}$ \\
\hline & $\begin{array}{l}\text { MGTMT } 6343 \\
\text { Contemporary Research in Man- } \\
\text { agement } \\
\text { (Research Methods I) }\end{array}$ & $\begin{array}{l}\text { BADM } 6533 \\
\text { Creativity, Innovation \& Leadership }\end{array}$ & Concentration Course I \\
\hline \multirow[t]{2}{*}{$\begin{array}{l}\text { Year } \\
2\end{array}$} & Concentration Course II & $\begin{array}{l}\text { FIN } 5333 \\
\text { Corporate Governance }\end{array}$ & Concentration Course III \\
\hline & $\begin{array}{l}\text { BADM } 6100 \\
\text { Applied Research Practicum II }\end{array}$ & $\begin{array}{l}\text { BADM } 6100 \\
\text { Applied Research Practicum III }\end{array}$ & $\begin{array}{l}\text { BADM } 6100 \\
\text { Applied Research Practi- } \\
\text { cum IV }\end{array}$ \\
\hline $\begin{array}{l}\text { Year } \\
3\end{array}$ & $\begin{array}{l}\text { BADM } 6000 \\
\text { Dissertation I }\end{array}$ & $\begin{array}{l}\text { BADM } 6000 \\
\text { Dissertation II }\end{array}$ & $\begin{array}{l}\text { BADM } 6000 \\
\text { Dissertation III }\end{array}$ \\
\hline
\end{tabular}

Source: Adapted from Oklahoma State University's Ph.D. for Business Executives website 


\section{Exhibit 7: Competing Programs near USF}

\begin{tabular}{|c|c|c|c|c|}
\hline \multirow{3}{*}{$\begin{array}{l}\text { Degree: Executive DBA } \\
\text { Credits: } 54 \\
\text { Cost: } \$ 78,500 \text { for } 3 \text { years } \\
\text { ( } \$ 1453 / \text { credit) } \\
\text { (Does not include books, meals; no expenses) }\end{array}$} & Year & Fall & Spring & Summer \\
\hline & 1 & $\begin{array}{l}\text { - Theory \& Contemporary } \\
\text { Thought in Economics } \\
\text { - Theory \& Contemporary } \\
\text { Thought in Leadership } \\
\text { - Introduction to the } \\
\text { Philosophy of Science } \\
\text { - Introduction to Research } \\
\text { Methods for Managers }\end{array}$ & $\begin{array}{l}\text { - Theory \& Contemporary } \\
\text { Thought in Finance } \\
\text { - Theory \& Contemporary } \\
\text { Thought in Marketing } \\
\text { - Introduction to } \\
\text { Quantitative Methods } \\
\text { - Introduction to } \\
\text { Qualitative Methods }\end{array}$ & $\begin{array}{l}\text { - Applied } \\
\text { Research } \\
\text { (Part 1)** }\end{array}$ \\
\hline & 2 & $\begin{array}{l}\text { - Theory \& Contemporary } \\
\text { Thought in Global } \\
\text { Business } \\
\text { - Theory \& Contemporary } \\
\text { Thought in } \\
\text { Organizational Behavior } \\
\text { and Human Resources } \\
\text { - Approved Elective } \\
\text { Course* }\end{array}$ & $\begin{array}{l}\text { - Theory \& Contemporary } \\
\text { Thought in Operations } \\
\text { Management } \\
\text { - Theory \& Contemporary } \\
\text { Thought in Strategy and } \\
\text { Strategic Marketing } \\
\text { - Approved Elective } \\
\text { Course* }\end{array}$ & $\begin{array}{l}\text { - Applied } \\
\text { Research } \\
\text { (Part 2)** }\end{array}$ \\
\hline \multirow{2}{*}{$\begin{array}{l}\text { RPC } 601 \text { and } 602 \text { Applied Research (Part } 1 \text { and Part 2) } \\
\text { An extended research project supervised by a faculty member. } \\
\text { DIS } 701 \text { and } 702 \text { Dissertation (Part } 1 \text { and Part 2) } \\
\text { The dissertation phase of the EDBA program provides the opportunity for each doctoral } \\
\text { student to develop and execute a complete research project that aims sto address practical } \\
\text { problems that are relevant within the student's own workplace or interest areas. The } \\
\text { dissertation is supervised by a committee of faculty consisting of a chair and a second } \\
\text { member. }\end{array}$} & 3 & $\begin{array}{l}\text { - Integrative Experience* } \\
\text { - Approved Elective } \\
\text { Course* }\end{array}$ & - Dissertation** & $\begin{array}{l}\text { - Dissertation } \\
{ }_{* *}\end{array}$ \\
\hline & \multicolumn{2}{|c|}{$\begin{array}{l}\text { Notes: Courses are } 1.5 \text { credits unless otherwise noted } \\
* 3 \text { Credit course } \\
* * 6 \text { Credifit course } \\
\end{array}$} & & \\
\hline
\end{tabular}

Source: Case writer slide derived from Rollins College, Crummer School's website

\section{Competitor: University of Florida Degree: DBA}

Credits: 60

Cost: $\$ 90,000$ for 3 years $(\$ 1500 /$ credit)

(Includes computer, meals, books, fees; no expenses)

- Fall of Year 1:

- Foundations Review: 12 half-day sessions where each half-day session consists of four hours of instruction (3 credit hours).

- Managerial Statistics: 6 days, 5.5 hours of instruction per day (3 credit hours).

- Terms (6): Participants take 6 credit hours in each term for a total of 36 credit hours. Courses in terms 1-6 have both an online and on-campus component.

- Comprehensive Exam: A three-stage process that takes places over the 3 years of the DBA program.

- Final Project: Terms 7, 8 and 9 are devoted to research symposiums and the final project (18 credit hours).

\begin{tabular}{|c|c|c|}
\hline Courses & Comprehensive Exam & Final Project \\
\hline \multicolumn{3}{|c|}{ - Accounting Research and Analysis: $($ show + ) } \\
\hline \multicolumn{3}{|c|}{ - Change Leadership: $($ show + ) } \\
\hline \multicolumn{3}{|c|}{ - Corporate Finance: $($ show + ) } \\
\hline \multicolumn{3}{|c|}{ - Entrepreneurship: $($ show +$)$} \\
\hline \multicolumn{3}{|c|}{ - International Business: $($ show + ) } \\
\hline \multicolumn{3}{|c|}{ - Managerial Economics: $($ show +$)$} \\
\hline \multicolumn{3}{|c|}{ - Marketing Strategy: $($ show + ) } \\
\hline \multicolumn{3}{|c|}{ - Organizational Behavior/HR: $($ show + ) } \\
\hline \multicolumn{3}{|c|}{ - Organizational Research Methods: (show + ) } \\
\hline \multicolumn{3}{|c|}{ - Quantitative Research Methods: (show +) } \\
\hline \multicolumn{3}{|c|}{ - Strategic Management: $($ show + ) } \\
\hline - Sup & ly Chain Strategy: (sho & \\
\hline
\end{tabular}

Source: Case writer slide derived from University of Florida's DBA website 


\section{Exhibit 8: USF DBA Summary Slides}

\section{Structure}

- 3 year program, leading to Executive Doctorate in Business degree

- 72 credits

- 52 credits course work

- 20 credits proposal and dissertation/project

- Designed for high level executives and managers

- Organized into cohorts with 25 or fewer students

- Blends online delivery and residencies at USF (10 weekends per year)

- Cost recovery program: Taught by faculty for extra compensation

Requirements

- Completion of all coursework with grades of B or better during 3-year period as part of cohort

- Participation in three or more academic conferences, symposia or workshops over the course of the program

- Qualifying exam, a pre-proposal demonstrating knowledge of research design

- Dissertation, supervised by 4 member committee, could consist of:

1. A traditional research dissertation

2. A practice-focused book submitted for publication

3. A write-up of a substantial work-related project in which the principles of evidence-based research were applied

4. A portfolio of related research products and activities that create knowledge or demonstrate an innovative application of research to a business situation.

Costs

Cost: Tuition of $\$ 90,000$ for 3 years $(\$ 1,250 /$ credit $)$

Includes:

- Tuition and fees

- Books and required course materials

- Continental breakfast, snacks, and lunch during weekend sessions

- A Windows Tablet PC and required software

- Up to $\$ 6,000$ for travel and research-related expenses associated with the program

Source: Case writer slides 


\section{Exhibit 9: Curriculum Graphic}

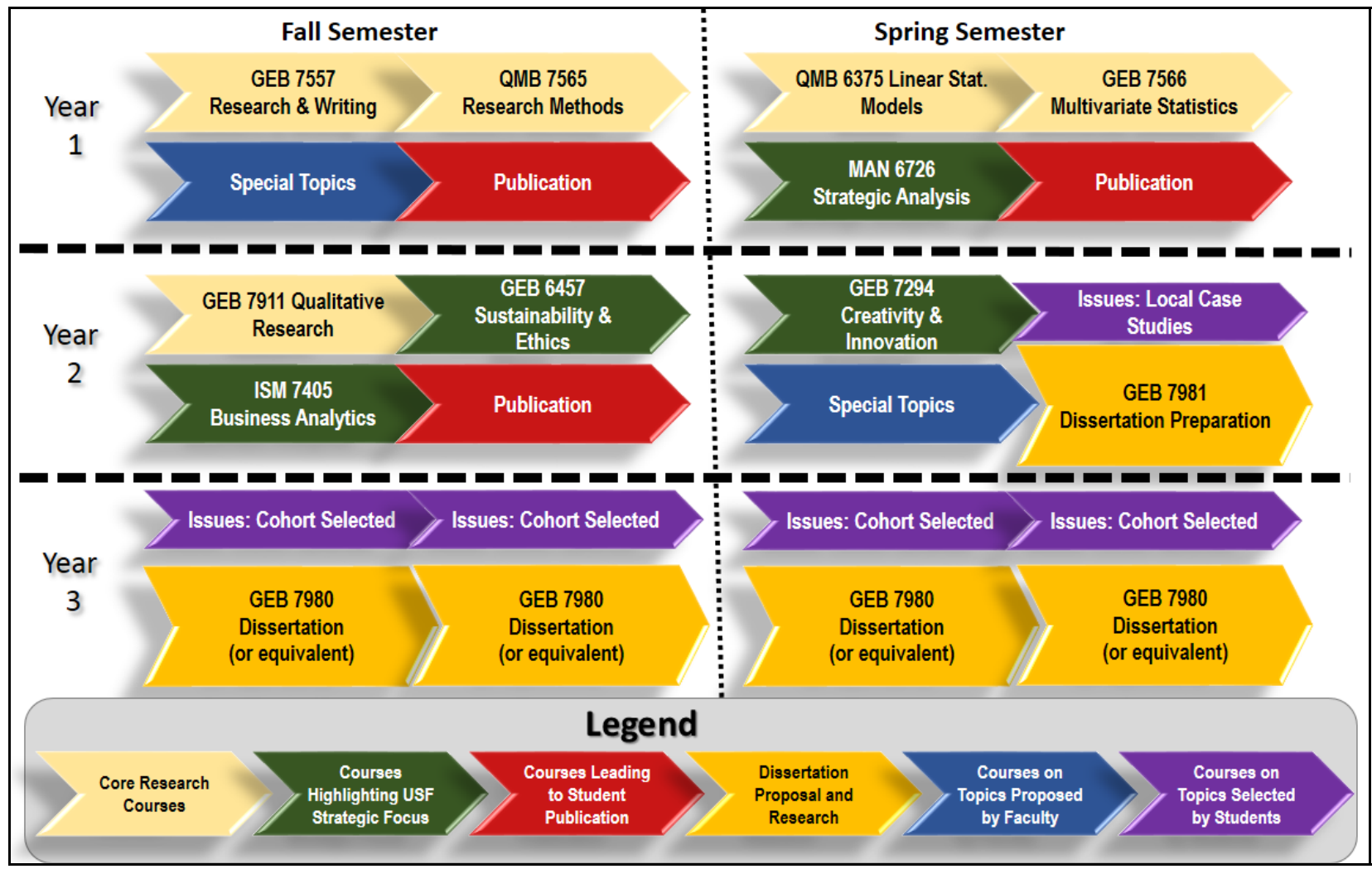

Source: USF DBA (development) website 


\section{Exhibit 10: Partners vs. Replica's blog posting ${ }^{4}$}

\section{The DBA Faculty-Student Relationship}

Posted on March 28, 2014 | Leave a comment | Edit

As we await the formal approval of the USF DBA program, I am continuing to jot down some of my own unofficial thoughts on the program in the blog. Today's topic: how I perceive the nature of the faculty-student relationships in the program.

This morning, I was asked to co-facilitate a session on how we might incorporate business analytics more effectively into our graduate curriculum. As part of my presentation, I asked the question: What are we trying to accomplish with our students? I might as well have been talking about the DBA program specifically.

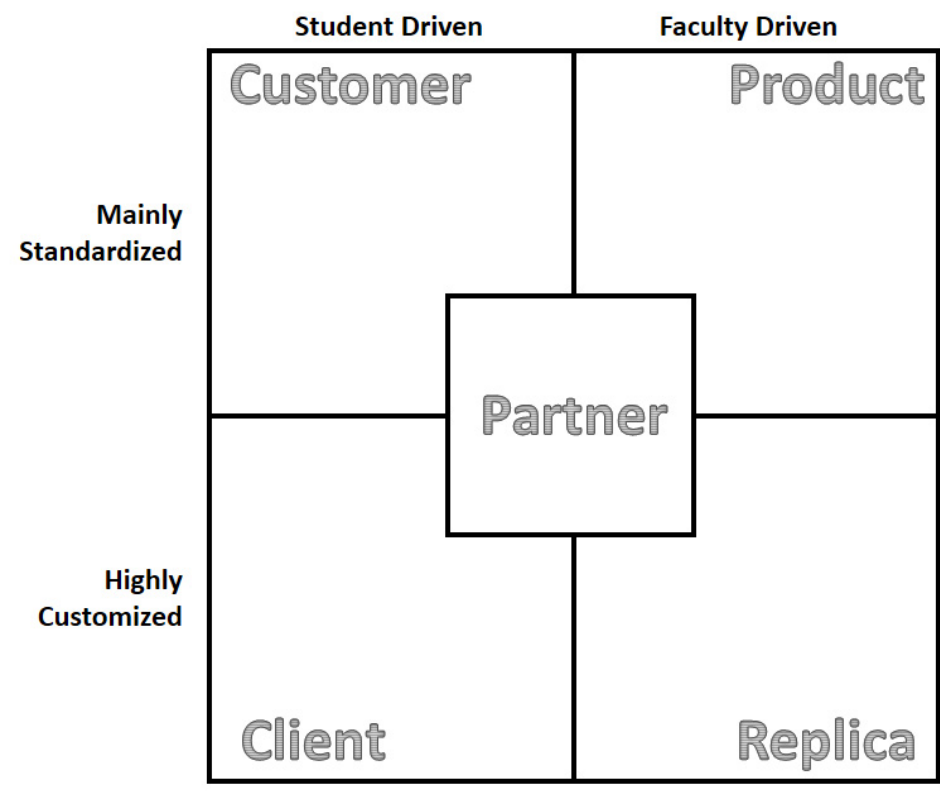

Relationships between faculty and students

To summarize, I see there being five distinct views that a faculty member might hold with respect to his or her relationship with students, as illustrated in the preceding figure. The key determinants of the relationship are: 1) who drives the process (student or faculty), and 2) degree of customization. The key issue with respect to the driver is: Who gets to decide when the process is complete? With respect to customization, the question is: How similar is the experience for different students?

The five relationships can be described as follows:

${ }^{4}$ Source: http://grandon.com/blog/?p=357 
1. Student as customer. With this relationship, the old adage "the customer is always right" would seem to apply. The principal goal the instructor needs to accomplish is to ensure that students are happy with what he or she is learning-the content is "the product". This is not as ridiculous as it might seem to a faculty member; to many students it probably makes sense right away, without need for further qualification. To my mind, most not-for-credit executive programs would do well to take this perspective. After all, executives are likely to know what they need on the job far better than most faculty members.

2. Student as product. At the opposite extreme, the faculty member could view the student as raw material awaiting transformation into a finished good. Here, future employers are "the customer". In this perspective, the student represents work-in-progress inventory, deserving of minimal input into what is being taught. This certainly seems reflective of prevailing attitudes in K-12, and works well with a teach-to-the-test approach. For it to make sense, however, we must assume that the instructor has a much clearer idea of what the student needs than the student does. The further along one's education progresses, the more arrogant this assumption seems.

3. Creating a replica of the instructor. This tends to be a highly customized process, like an apprenticeship, whose ultimate goal is to create a future replica of the master, sharing the same skills and values. The master decides what the student needs because the master knows precisely what skills and values must be passed on if a replica of himself or herself is to be the end result. If I were to characterize traditional academic Ph.D. programs, I believe that this model is the closest. I have often heard faculty talk about "socializing" their doctoral students. To me, this seems to be mainly a matter of getting them to act like us. The academic research world is highly competitive, however. All things being equal, it probably makes sense for a doctoral student to imitate a successful faculty member if he or she wants to succeed. And many do.

4. Student as client. This relationship is involves a highly customized one-on-one relationship normally initiated and controlled by the student. Examples might be a tutor or music instructor. The client relationship implies the type of exchange of information that takes place between a professional (e.g., doctor, lawyer, accountant, architect, etc.) and his or her client. In such relationships, both parties are assumed to hold knowledge that is critical to the success of the undertaking.

5. Student as future partner. In this relationship, control is shared between student and faculty, and there is likely to be a mix of standardized and customized content. The "future partner" aspect comes in with respect to answering the original question: What are we trying to accomplish with our students? In this relationship, the assumption is that once the "education" ends, a longer term relationship will commence. A partner is not a clone-anyone who has been married will tell you that. Rather, we tend to choose partners whose skills complement our own.

As should be immediately obvious, I strongly favor the last of these models for our DBA program. I frequently assert that one of the greatest scandals in business education is the monumental failure of our (very expensive!) research agenda to impact practice. I see a number of reasons for this:

- It is hard to move ideas and innovations between very different communities of individuals. Always has been, always will be. There's plenty of research into diffusion to back me up here.

- Publications are a very weak tool for conveying complex knowledge. So any assumption that we academics make regarding the "impact" of our publications is largely self-serving. What it really means is that other academics who share the same core set of ideas with us will, from time-to-time, mention what we have written without necessarily being influenced by it in any material way.

- General theories lack the context to be useful in practice. Academics thrive on the creation of "theory". Such theory is largely assumed to be generalizable (by its creators) until proven otherwise. And, as an aside, it is considered a bit of a scholarly faux pas to "prove otherwise" in business research. By virtue of the very nature of complexity, however, the context of an activ- 
ity will nearly always exert a major influence on the outcome of the activity. Thus, without someone to supply context, theory becomes sterile, if not puerile.

- Practitioners tend to be more interested in solving problems than in plugging holes in the research literature. This represents a significant divergence between practitioners and research academics. Lacking common objectives, it is hard for members of either group to get very excited about working with members of the other.

Given these obstacles, it seems amazing that any ideas move between practitioners and researchers. But, like all generalizations, there tend to be a small number of exceptions to the rules just described. Within any community, there tend to be a few individuals-Malcolm Gladwell refers to them as "Mavens" in his book The Tipping Point-who just want to know as much as they can. These mavens can serve as a bridge between very different communities, as they did during the revolution that transformed U.S. agriculture over the past 150 years.

This is how I see the students in our DBA program. In a sense, the program might be considered a "maven trap" (another term used by Gladwell) because it is perfectly suited to attract this type of individual. Once in the program, faculty and these individuals will develop professional/client relationships (although I cannot commit to identifying which is which) that will blossom into enduring partnerships for research and problem solving once the doctoral candidate graduates. Both sides will want these relationships. The executives can provide access to sites for future research and even, perhaps, consulting opportunities for researchers. The faculty researchers, for all their foibles, have much to offer as well. They are good problem solvers and strong conceptual thinkers. Moreover, they have the slack in their schedules needed to really get into a particular problem. That is a luxury that many executives lack.

Of course, such relationships do not come for free. Any program that seeks to achieve such long term partnerships needs to be designed to foster them. There are many aspects of the USF DBA's design that were intended to achieve just that. The "Issues" courses at the end of the program are constructed so students can partner with faculty to request and even co-teach courses while they are in the program. Once they leave, they can propose and teach courses for future cohorts. Particularly critical, our plan has always been to have alumni of the program actively participate in the dissertation committees. Not only will that serve to maintain and strengthen the relationships established during the program, it will also reduce the demands that the huge advising needs of the program place on our faculty. Finally, our conference requirement-students must attend three conferences or faculty workshops over the course of the program (supported by a $\$ 6000$ expense budget built into their tuition)-helps student become better acquainted with research as practiced by regular research faculty. At least they will come to know our culture, even if we remain a bit weak on theirs.

My personal belief is that the types of partnerships we seek to forge in this program could transform how we think about business research. Perhaps, some day in the future, when we talk about the impact of our research, we will actually mean impact that people can see and even measure.

\section{Of course, this is my decidedly unofficial opinion.}




\section{Exhibit 11: USF DBA “Development” Website}

\section{College of Business}

COMING SOON: DOCTOR OF BUSINESS ADMINISTRATION

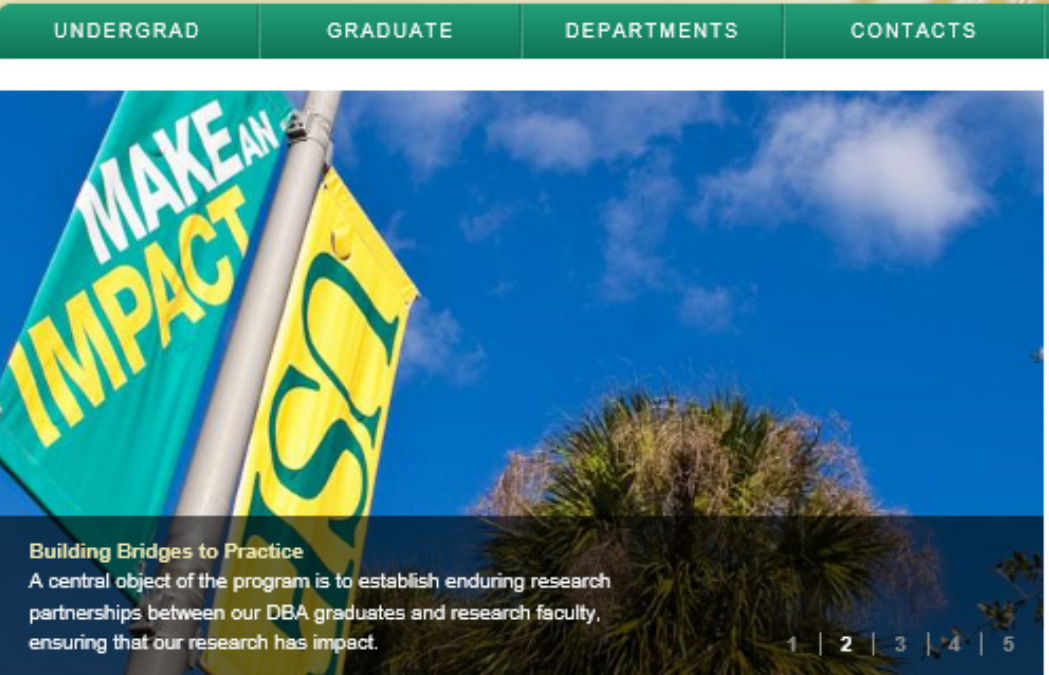

$$
\text { CENTERS }
$$

ABOUT US

NEWS

Executive PhDs: Call me a doctor

Tuesday, October 22, 2013

Amidst M.B.A. Inflation, Executives Recommend.

Friday, February 17, 2013

Executive PhD Programs Find U.S. Market

Sunday, October 17, 2013

PhD Programs for Executives Gain Traction

Monday, August 16, 2013

\section{UPCOMING EVENTS}

\section{JUN Fall Admission Deadline \\ 01 7:30 AM - 8:30 AM}

What is a DBA?

Curriculum

Information Sessions

Admission

Costs/Financial Aid

Fall 2014 Schedule

FACULTY SPOTLIGHT

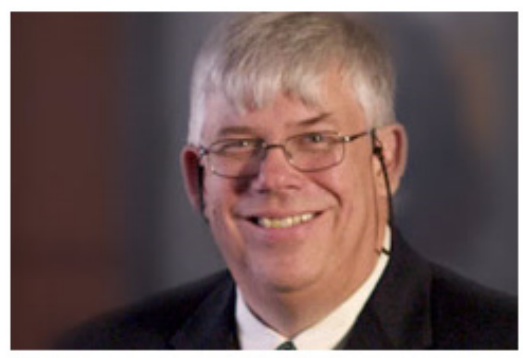

Grandon Gill, a professor in the Information Systems and Decision Sciences department, is the incoming director designate. He has a DBA is from Harvard Business School (as well as an MBA) and stands ready to answer your questions. Contact him by email at grandon@usf.edu. 


\section{Exhibit 12: DBA Page on Gill's Personal Website}

\section{Grandon Gill's Website

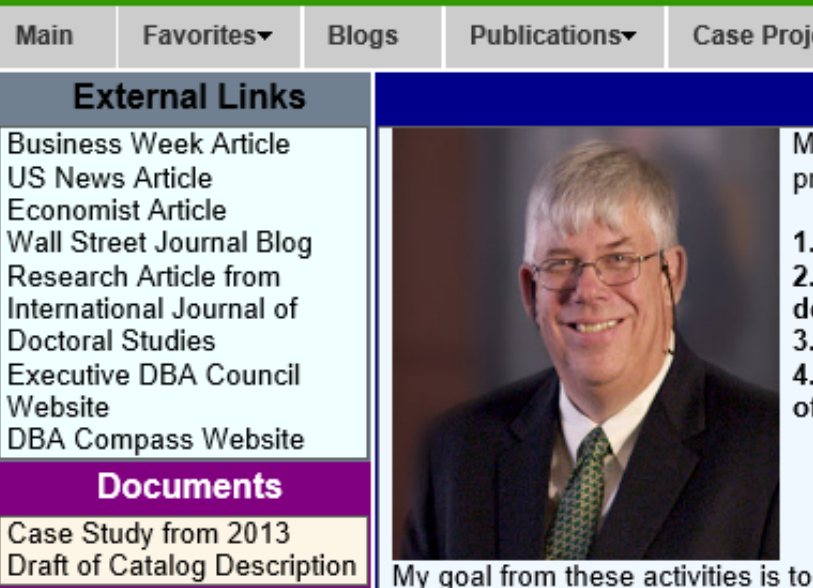

\section{DBA Blog}

USF DBA Program Design

Wed, 02 Apr 2014 21:19:04 $+0000$

As the USF DBA program

for working executives gets

ready to launch, I thought I

would jot down some of my

personal (and unofficial)

thoughts about its design.

Curriculum l've put the

curriculum graphic I created

in a number of other

Continue reading $\rightarrow$

Executive DBA Program

Structures Sat, 29 Mar

2014 17:20:00 +0000

In this post I thought that I

would briefly outline the

four different structures that

I have observed in

executive doctorates, three

of which can be found in

the U.S. This parallels the

4th video in my youtube

series on ... $\underline{\text { Continue }}$

reading $\rightarrow$

The DBA Faculty-Student

Relationship Fri, 28 Mar

2014 22:06:16 +0000

As we await the formal

approval of the USF DBA

program, I am continuing to

that USF's program gets off to a promising start.

\section{Announcement}

The University of South Florida College of Business has just announced a new program in the final stages of approval:

\section{Doctor of Business Administration}

The purpose of the of the program is to provide working executives with the opportunity to pursue a doctoral degree that will allow them to develop research skills that they can apply to their business activities and that will qualify them to teach in business programs at the graduate level, particularly in a part-time capacity.

The program is expected to recieve final approval by the end of April. In the meantime, the temporary (development) website for the program can be accessed at: USF DBA Development Website

\section{DBA Degree Overview Videos}

\begin{tabular}{|l|l|l|l|l|l|l|}
\hline Part 1 & Part 2 & Part 3 & Part 4 & Part 5 & Part 6 & Part 7 \\
\hline
\end{tabular}

:E- PLAYLIST 1. $^{1 / 7}$ Executive Doctorate Series $<$

1. Introduction to the series

2. What is a DBA/Executive Doctorate?

3. Common characteristics
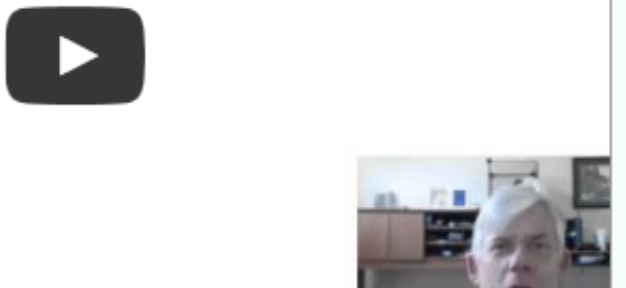


\section{Exhibit 13: Florida Executive Doctorate Programs}

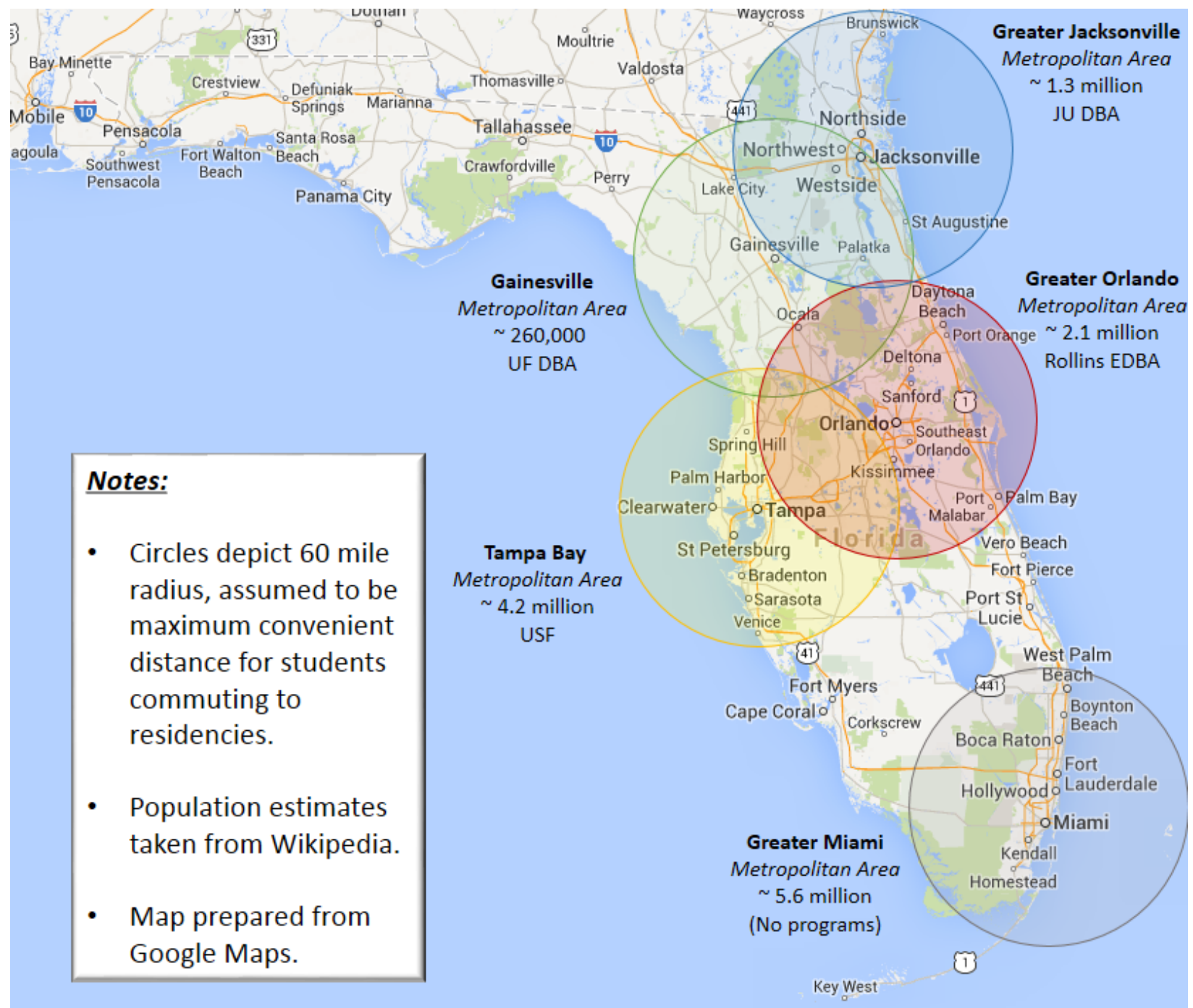

Source: Prepared by case writer. 


\section{Exhibit 14: Estimated Budget Breakdown}

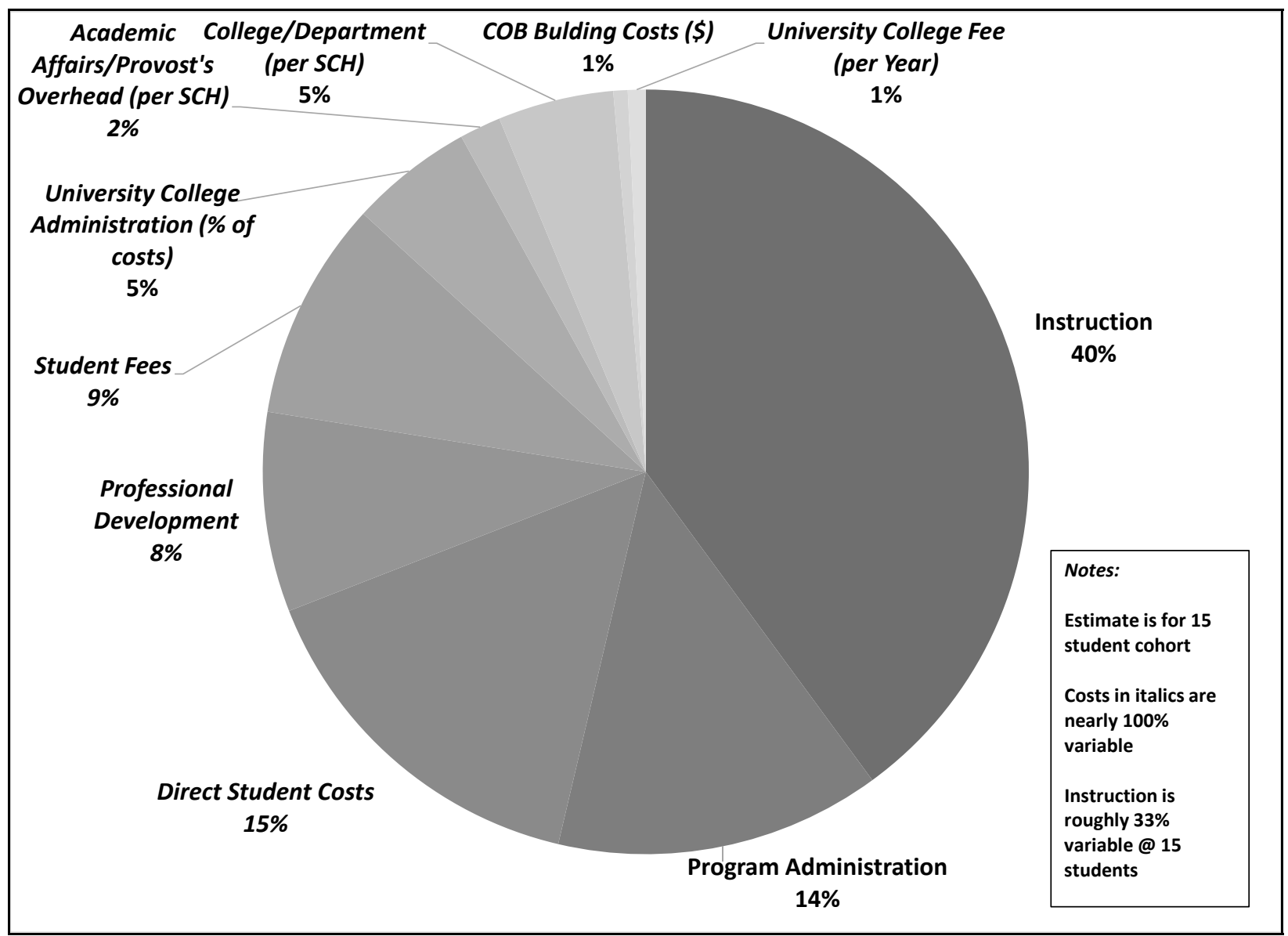

Source: Prepared by case writer. 